\title{
Determinan Individu Untuk Social Commerce: Kajian Theory of Planned Behavior dan Technology Acceptance Model
}

Amir Hidayatulloh*, Rizky Maulana**, Agung Dwi Nugroho ${ }^{* * *}$

*,*****Universitas Ahmad Dahlan, Yogyakarta, Indonesia, amir.hidayatulloh@act.uad.ac.id

\section{ARTICLE INFO}

\section{Article history:}

Received 26 Februari 2019

Received in Revised 29 April 2019

Accepted 14 April 2019

Keywords:

Social Commerce, Theory of Planned

Behavior, Technology Acceptance

Model
ABSTRACT

The objective of study is to determine the determinants of social media use for social commerce. These factors are associated with theory of planned behavior and technology acceptance model. Population in this study is internet users, while the sample of this study is social media users. Sampling technique using purposive sampling. Criteria used is respondent who have made purchase through social media at least two time the purchase. This research uses SEMPLS analysis tool, in this case that is WarpPLS. Result of this study is perceived usefulness, perceived easy have a positive effect on user's attitude towards social media, which ultimately the user's attitude towards social media also affect the intention of respondent to make purchase through social media (social commerce). In addition, perceived usefulness is affect the perceived ease use. However, perceived usefulness, subjective norm, an perceived behavior control has no effect on the respondent's intention to make purchase through social media.

Tujuan penelitian ini adalah untuk mengetahui faktor penentu penggunaan media sosial untuk social commerce. Faktor tersebut dikaitkan dengan theory of planned behavior dan technology acceptance model. Populasi dalam penelitian ini adalah pengguna internet, sedangkan sampel penelitian ini adalah pengguna media sosial. Teknik pengambilan sampel menggunakan purposive sampling. Kriteria yang digunakan yaitu responden yang telah melakukan pembelian melalui media sosial minimal dua kal pembelian. Penelitian ini menggunakan alat analisis SEMPLS, dalam hal ini yaitu WarpPLS. Penelitian ini memperoleh hasil bahwa persepsi kegunaan, kemudahaan penggunaan persepsian berpengaruh positif terhadap sikap pengguna terhadap media sosial, yang akhirnya sikap pengguna terhadap media sosial juga mempengaruhi niat responden untuk melakukan pembelian melalui media sosial. Selain itu, kegunaan persepsian dipengaruhi oleh kemudahaan penggunaan persepsian. Namun, kegunaan persepsian, norma subjektif, dan kontrol perilaku persepsian tidak berpengaruh pada niat responden untuk melakukan pembelian melalui media sosial.

AKUISISI : Jurnal Akuntansi

Website : http://www.fe.ummetro.ac.id/ejournal/index.php/JA

This is an open access article distributed under the terms of the Creative Commons Attribution 4.0 International License, which permits unrestricted use, distribution, and reproduction in any medium, provided the original work is properly cited.

E-mail address: amir.hidayatulloh@act.uad.ac.id

Peer review under responsibility of Akuisisi : Accounting Journal. 2477-2984.

http://dx.doi.org/10.24217 


\section{PENDAHULUAN}

Kementerian Komunikasi dan Informasi Republik Indonesia pada lamannya mengungkapkan bahwa pengguna internet di Indonesia mencapi 63 juta orang, dan 95\% dari pengguna internet menggunakan jaringan internet untuk mengakses media sosial. Lebih lanjut, laman Kementerian Komunikasi dan Informasi Republik Indonesia juga menampilkan data dari Webershandwick (perusahaan public relation dan pemberi layanan jasa komunikasi), wilayah Indonesia 65 juta merupakan pengguna facebook aktif, 33 juta pengguna facebook aktif perharinya, 55 juta pengguna aktif mengakses facebook melalui mobile per bulan, serta 28 juta pengguna aktif mengakses facebook melalui mobile per harinya. Oleh karena itu, dilaman tersebut dinyatakan bahwa Indonesia merupakan pengguna facebook diurutan keempat setelah USA, Brazil, dan India (http://kominfo.co.id, dilihat tanggal 02 November 2016, Pukul 05:30).

Kepopuleran dari media sosial menjadikan alat pendukung bagi aktivitas bisnis, khususnya dalam aktivitas bisnis online. Oleh karena itu, muncul paradigma baru pada perdagangan yaitu social commerce (Ashur, 2016; Huang dan Benyoucef, 2013; Zhou et al. 2013; Shin, 2013; Liang et al., 2012; Stephen dan Toubia, 2010; Dennison et al., 2009). Social commerce (S-commerce) didefinisikan sebagai strategi yang memanfaatkan situs media sosial untuk memfasilitasi perdagangan berbagai produk dan jasa (Hajli, 2014; Kim dan Park, 2013).

Penelitian ini terinspirasi dari penelitian Smith et al. (2013) yang meneliti mengenai social commerce yang ditinjau dari paragdigma teori perilaku rencanaan (theory of planned behavior). Smith et al. (2013) memperoleh hasil bahwa sikap, norma subjektif, dan kontrol perilaku persepsian berpengaruh terhadap niat untuk melakukan pembelian. Akan tetapi, faktor terbesar yang menentukan niat individu untuk melakukan pembelian adalah norma subjektif.

Penelitian ini mempunyai perbedaan dengan penelitian sebelumnya. Penelitian ini tidak hanya menggunakan theory of planned behavior, namun penelitian ini juga menggunakan model penerimaan teknologi (technology acceptance model). Alasan penggunaan theory of planned behavior yaitu seperti yang diungkapkan oleh Smith et al. (2013), bahwa teori perilaku perencanaan cocok diterapkan pada perilaku dibawah kendali kehendak seseorang (volitional control). Volitional control berlaku untuk kapasitas mental individu untuk bertindak secara bebas dan disertai pemahaman atas konsekuensinya. Keterlibatan individu dalam s-commerce merupakan suatu kehendak sehingga teori perilaku rencanan dapat digunakan untuk memprediksi niat pembelian secara online (Smith et al., 2013).

Penggunaan model penerimaan teknologi (technology acceptance model) karena model penerimaan teknologi merupakan salah satu teori tentang penggunaan sistem teknologi informasi yang dianggap sangat berpengaruh dan secara umum digunakan untuk menjelaskan penerimaan individu terhadap penggunaan sistem (Hartono, 2007:111). Technology acceptance model memiliki ciri-ciri teori yang baik, sederhana, didukung oleh data (verifiability), serta technology acceptance model dapat diterapkan dalam memprediksi penerimaan dan penggunaan sebuah hasil dalam berbagai bidang (generalability) (Ramadhani, 2007). Oleh karena itu, model penerimaan teknologi cocok digunakan untuk menjelaskan penerimaan individu terhadap media sosial. Dari uraian sebelumnya, maka peneliti tertarik untuk menganalisis faktor penentu penggunaan media sosial untuk social commerce dari paradigma theory of planned behavior dan technology acceptance model. 


\section{METODE PENELITIAN}

\subsection{Populasi dan Sampel}

Populasi dalam penelitian ini adalah pengguna internet. Sedangkan, sampel dalam penelitian ini adalah pengguna media sosial. Teknik pengambilan sampel dalam penelitian menggunakan purposive sampling, dengan kriteria bahwa pengguna media sosial tersebut sudah pernah melakukan pembelian melalui media sosial minimal dua kali. Penelitian ini menggunakan teknik pengumpulan data survei dengan menggunakan kuesioner yang dikirimkan lewat komputer, dalam hal ini memanfaatkan fasilitas google form. Alasan penggunaan teknik pengumpulan data survei dengan menggunakan kuesioner yaitu karena penelitian ini mempunyai tujuan untuk mendapatkan data opini individu.

\subsection{Definisi Operasional dan Pengukuran Variabel}

\section{a. Variabel Dependen}

Variabel dependen dalam penelitian ini adalah niat untuk melakukan pembelian melalui media sosial. Niat untuk melakukan pembelian melalui media sosial didefinisikan sebagai keinginan individu untuk melakukan pembelian, khususnya melalui media sosial (Hartono, 2007). Niat untuk melakukan pembelian melalui media diukur dengan menggunakan dua item pertanyaan yang diadopsi dari Davis et al. (1989); Indrayana et al. (2016). Pernyataan yang terkait dengan niat untuk melakukan pembelian melalui media sosial diukur dengan skala likert 5 poin (sangat tidak setuju (1) sampai dengan sangat setuju (5)).

\section{b. Variabel Independen}

Variabel independen dalam penelitian ini adalah kegunaan persepsian, kemudahaan penggunaan persepsian, norma subjektif, kontrol perilaku persepsian, dan sikap pengguna terhadap media sosial.

\section{Kegunaan Persepsian}

Kegunaan persepsian adalah suatu ukuran dimana penggunaan teknologi dipercaya akan mendatangkan manfaat bagi individu yang menggunakannya (Davis et al., 1989). Kegunaan persepsian diukur dengan dua item pertanyaan yang diadopsi dari Davis et al. (1989); Indrayana et al. (2016). Pertanyaan yang terkait dengan kegunaan persepsian diukur dengan skala likert 5 poin (sangat tidak setuju (1) sampai dengan sangat setuju (5)).

\section{Kemudahaan Penggunaan Persepsian}

Kemudahaan penggunaan persepsian adalah tingkat keyakinan seseorang bahwa menggunakan sistem tertentu tidak membutuhkan usaha keras (Davis et al., 1989). Kemudahaan penggunaan persepsian diukur dengan menggunakan tiga item yang diadopsi Davis et al. (1989); Indrayana et al. (2016). Pertanyaan yang terkait dengan kemudahaan penggunaan persepsian diukur dengan skala likert 5 poin (sangat tidak setuju (1) sampai dengan sangat setuju (5)).

\section{Norma Subjektif}

Norma subjektif adalah tekanan sosial yang dipersepsikan untuk melakukan atau tidak melakukan suatu perilaku tertentu (Ajzen dan Fishbein, 1980; Ajzen, 1991). Norma subjektif diukur dengan menggunakan dua item yang diadopsi Davis et al. (1989); Indrayana et al. (2016). Pertanyaan yang terkait dengan norma subjektif diukur dengan skala likert 5 poin (sangat tidak setuju (1) sampai dengan sangat setuju (5)).

\section{Kontrol Perilaku Persepsian}

Kontrol perilaku persepsian adalah persepsi individu mengenai mudah atau tidaknya individu untuk melakukan suatu perilaku (Ajzen, 1988). Kontrol perilaku persepsian diukur dengan menggunakan dua item yang diadopsi Davis et al. (1989); Indrayana et al. (2016). 
Pertanyaan yang terkait dengan kontrol perilaku persepsian diukur dengan skala likert 5 poin (sangat tidak setuju (1) sampai dengan sangat setuju (5)).

\section{Sikap Pengguna Terhadap Media Sosial}

Sikap pengguna terhadap media sosial adalah suatu evaluasi menyeluruh mengenai media sosial, sehingga individu merespon baik dengan cara yang menguntungkan maupun cara yang tidak menguntungkan (Engel et al., 1994). Sikap pengguna terhadap media sosial diukur dengan menggunakan dua item pertanyaan yang diadopsi dari Davis et al. (1989); Indrayana et al. (2016). Pertanyaan yang terkait dengan sikap pengguna terhadap media sosial diukur dengan skala likert 5 poin (sangat tidak setuju (1) sampai dengan sangat setuju (5)).

\section{a. Metode Analisis}

Penelitian ini menggunakan alat analisis SEM PLS. Rerangka penelitian ini dapat digambarkan sebagai berikut.

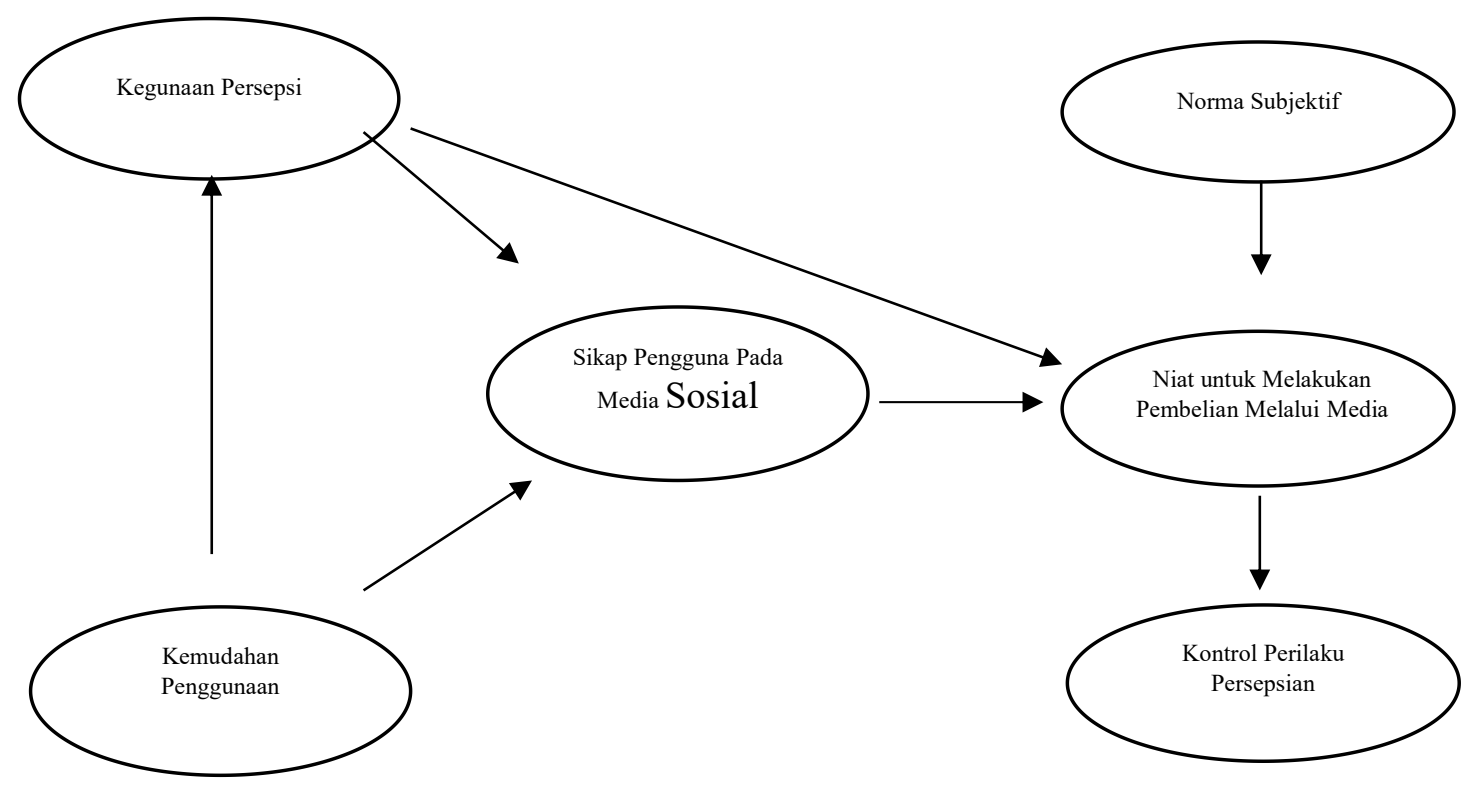

Gambar 1. Rerangka Penelitian

\section{b. Pengaruh Kegunaan Persepsian Pada Sikap Pengguna Terhadap Media Sosial}

Pradana et al. (2016) mengungkapkan bahwa pemanfaatan suatu sistem teknologi informasi dapat meningkatkan kinerja pengguna, sehingga pengguna akan memanfaatkan sistem teknologi tersebut apabila terbukti bermanfaat dalam pekerjaannya. Persepsi kegunaan merupakan persepsi (hal) yang paling mempengaruhi sikap, minat menggunakan, serta perilaku individu dalam menggunakan suatu teknologi dibandingkan dengan persepsi (hal) lainnya. Davis et al. (1989) mengungkapkan bahwa perilaku individu untuk menggunakan suatu teknologi ditentukan oleh niat individu untuk menggunakan teknologi tersebut, sedangkan niat untuk menggunakan teknologi ditentukan oleh sikap pengguna pada teknologi tersebut. Sikap tersebut ditentukan oleh persepsi kegunaan dan persepsi kemudahaan kegunaan pada teknologi tersebut.

Putri dan Suprapti (2016) menyatakan bahwa persepsi kegunaan menentukan niat menggunakan m-commerce secara tidak langsung melalui sikap penggunaan. Hal ini didukung oleh hasil penelitian Sari dan Hermanto (2016). Sari dan Hermanto (2016) menemukan hasil bahwa persepsi kegunaan berpengaruh positif terhadap sikap penggunaan. Dari kaji teori dan hasil penelitian terdahulu, maka hipotesis pertama penelitian ini yaitu sebagai berikut:

$\mathbf{H}_{1}$ : Kegunaan persepsian berpengaruh positif pada sikap pengguna terhadap media sosial. 


\section{c. Pengaruh Kemudahaan Penggunaan Persepsian Pada Sikap Pengguna Terhada Media Sosial}

Santoso (2010) mengungkapkan bahwa konsep kemudahan penggunaan persepsian menunjukan tingkatan individu meyakini bahwa penggunaan suatu teknologi adalah mudah dan tidak membutuhkan usaha keras untuk menggunakannya. Oleh karena itu, individu akan menggunakan suatu teknologi ketika teknologi tersebut mudah digunakan. Pendapat ini didukung oleh hasil penelitian Putri dan Suprapti (2016); Salsabila et al. (2016). Hasil penelitian yang diperoleh Putri dan Suprapti (2016) yaitu persepsi kemudahaan penggunaan menentukan niat menggunakan $m$-commerce secara tidak langsung melalui sikap penggunaan. Begitu juga, Salsabila et al (2016), kemanfaatan mempunyai pengaruh positif dan signifikan terhadap sikap penggunaan. Dari kaji teori dan penelitian terdahulu, maka hipotesis kedua penelitian ini yaitu sebagai berikut:

$\mathbf{H}_{2}$ : Kemudahaan penggunaan persepsian berpengaruh positif pada sikap pengguna terhadap media sosial

\section{d. Pengaruh Kemudahaan Penggunaan Persepsian Pada Kegunaan Persepsian}

Heriyanti et al. (2013) menganalisis belanja online melalui smartphone, dan memperoleh hasil bahwa persepsi kemudahan penggunaan smartphone berpengaruh signifikan terhadap persepsi manfaat smartphone untuk belanja online. Oleh karena itu, tinggi rendahnya persepsi kemudahaan menentukan kuat lemahnya persepsi manfaat. Satu tahun berikutnya, Tirtana dan Sari (2014) mengungkapkan ketika jasa yang diberikan oleh teknologi dipersepsikan mudah digunakan oleh pengguna maka akan mendorong pengguna untuk menerima dan menggunakan teknologi tersebut. Lebih lanjut, hasil penelitian Tirtana dan Sari (2014) yaitu persepsi kemudahaan penggunaan dalam e-bill akan mempengaruhi persepsi kegunaan yang digambarkan sebagai kemudahaan yang dirasakan oleh pengguna dalam menggunakan $e$-bill akan memudah akses pengguna untuk menemukan informasi yang dibutuhkan. Hal ini selaras dengan hasil penelitian Paramitha dan Mujahidin (2014); Sari dan Hermanto (2016). Oleh karena itu, dari kaji teori dan hasil penelitian sebelumnya, maka hipotesis ketiga penelitian ini yaitu sebagai berikut:

$\mathbf{H}_{3}$ : Kemudahaan penggunaan persepsian berpengaruh positif pada kegunaan persepsian.

\section{e. Pengaruh Kegunaan Persepsian Terhadap Niat Untuk Melakukan Pembelian Melalui Media Sosial}

Putri dan Suprapti (2016) mengungkapkan bahwa persepsi manfaat yang dirasakan mempunyai pengaruh terhadap niat individu untuk menggunakan m-commerce. Hasil ini didukung oleh Davis et al. (1989); Thakur dan Srivastaya (2013). Thakur dan Srivastaya (2013) menemukan bahwa persepsi manfaat merupakan salah satu dimensi dari technology acceptance model yang menerangkan m-commerce. Pradana et al. (2016) melakukan penelitian yang menggunakan technology acceptance model. Penelitian Pradana et al. (2016) menemukan bahwa niat menggunakan software salah satunya didorong oleh persepsi manfaat yang dirasakan oleh individu. Oleh karena itu, dari uraian hasil penelitian terdahulu, maka hipotesis keempat penelitian ini yaitu sebagai berikut:

$\mathbf{H}_{4}$ : Kegunaan persepsian berpengaruh positif terhadap niat untuk melakukan pembelian melalui media sosial.

\section{f. Pengaruh Sikap Pengguna Pada Media Sosial Terhadap Niat Untuk Melakukan Pembelian Melalui Media Sosial}

Bagozzi (1991) mengungkapkan bahwa terdapat hubungan antara sikap dengan niat untuk melakukan. Pendapat ini didukung oleh Davis et al. (1989), yang menyatakan bahwa keinginan untuk menggunakan teknologi baru salah satunya dipengaruh oleh sikap individu terhadap penggunaannya. Hal ini didukung oleh Putri dan Suprapti (2016), yang mengungkapkan bahwa kegunaan persepsian dan persepsi kemudahaan penggunaan menentukan niat menggunakan mobile commerce secara langsung melalui sikap penggunaan. 
Oleh karena itu, dari hasil penelitian sebelumnya, maka hipotesis kelima penelitian ini yaitu sebagai berikut:

H5: Sikap pengguna pada media sosial berpengaruh positif terhadap niat untuk melakukan pembelian melalui media sosial.

g. Pengaruh Norma Subjektif Terhadap Niat Untuk Melakukan Pembelian Melalui Media Sosial

Theory of planned behavior menyatakan bahwa niat individu akan menentukan perilaku individu tersebut. Niat dibentuk oleh sikap, norma subjektif, dan kontrol perilaku persepsian. Pendapat ini didukung oleh penelitian Smith et al. (2013), yang mengungkapkan bahwa niat untuk melakukan pembelian melalui social commerce mempunyai hubungan yang positif dengan norma subjektif. Hasil ini didukung oleh Binalay et al. (2016) yang mengungkapkan bahwa norma subjektif berpengaruh terhadap minat untuk melakukan pembelian secara online. Oleh karena itu, dari hasil penelitian sebelumnya, maka hipotesis keenam penelitian ini yaitu sebagai berikut:

$\mathbf{H}_{6}$ : Norma Subjektif berpengaruh positif terhadap niat untuk melakukan pembelian melalui media sosial.

h. Pengaruh Kontrol Perilaku Persepsian Terhadap Niat Untuk Melakukan Pembelian Melalui Media Sosial

Niat individu menurut theory of planned behavior dibentuk oleh sikap, norma subjektif, dan kontrol perilaku persepsian. Pendapat ini didukung oleh hasil penelitian Smith et al. (2013), yang menemukan bahwa kontrol perilaku persepsian dan niat untuk melakukan pembelian melalui social commerce mempunyai hubungan yang positif. Oleh karena itu, hipotesis ketujuh penelitian ini yaitu sebagai berikut:

H7: Kontrol perilaku persepsian berpengaruh positif terhadap niat untuk melakukan pembelian melalui media social.

\section{HASIL DAN DISKUSI}

Responden penelitian ini berjumlah 145 responden, dan 66,9\% berjenis kelamin lakilaki serta 33,1\% berjenis kelamin perempuan. Usia responden disajikan pada tabel 1 .

Tabel 1.

\section{Deskriptif Responden}

\begin{tabular}{|c|c|}
\hline Usia & Presentase \\
\hline 15-20 Tahun & $52,4 \%$ \\
\hline 21-25 Tahun & $37,2 \%$ \\
\hline 26-30 Tahun & $08,3 \%$ \\
\hline 31-35 Tahun & $00,7 \%$ \\
\hline 36-40 Tahun & $01,4 \%$ \\
\hline
\end{tabular}

Sumber: Data diolah (2017)

Tabel 1 menjelaskan usia responden penelitian ini. Usia responden penelitian ini didominasi oleh usia 15-10 tahun. Tiga media sosial yang digunakan responden penelitian ini yaitu instragram, website, dan facebook.

\section{Pengujian Hipotesis}


Penelitian ini membangun hipotesis yang bertujuan untuk memprediksi model guna pengembangan model. Sehingga, partial least square (PLS) tepat digunakan. PLS sebagai persamaan struktural (SEM) berbasis varian yang secara simultan dapat melakukan pengujian model pengukuran dan pengujian model structural. Model pengukuran digunakan untuk uji validitas dan reliabilitas. Sedangkan, model struktural digunakan untuk pengujian hipotesis dengan model prediksi (kausalitas) (Hartono dan Abdillah, 2014).

\section{Model Pengukuran (Outer Model)}

Tahap purifikasi dalam model pengukuran harus dilakukan agar suatu konsep dan model penelitian dapat diuji dalam model prediksi hubungan relasional dan kausal. Model pengukuran digunakan untuk menguji validitas konstruk dan reliabilitas instrumen (Hartono dan Abdillah, 2014).

\section{a. Uji Validitas}

Uji validitas dilakukan dalam penelitian ini bertujuan untuk mengetahui kemampuan instrument penelitian mengukur apa yang seharusnya diukur. Validitas terdiri dari validitas internal dan validitas eksternal. Validitas eksternal adalah kemampuan data untuk digeneralisasi untuk objek, waktu, dan tempat. Sedangkan, validitas internal merupakan kemampuan instrumen penelitian untuk mengukur apa yang seharusnya diukur (Cooper dan Schilender, 2006).

Penelitian ini melakukan pengujian validitas konstruk. Validitas konstruk meliputi validitas konvergen dan validitas diskriman. Validitas konvergen berhubungan dengan prinsip pengukur dari konstruk seharusnya tinggi, sedangkan validitas diskriminan berhubungan bahwa pengukur konstruk yang berbeda seharusnya tidak berkorelasi tinggi (Hartono, 2008). Hasil uji validitas disajikan pada tabel 2.

Tabel 2

Hasil Uji Validitas

\begin{tabular}{|c|c|c|c|c|c|c|c|}
\hline Ket & $\mathbf{K P}$ & PK & $\mathbf{N}$ & NP & KPE & $\mathbf{S}$ & AVE \\
\hline KP1 & $(0,832)$ & & & & & & \multirow{2}{*}{0,697} \\
\hline KP2 & $(0,802)$ & & & & & & \\
\hline PK_1 & & $(0,753)$ & & & & & \multirow{3}{*}{0,605} \\
\hline PK_2 & & $(0,779)$ & & & & & \\
\hline PK_3 & & $(0,760)$ & & & & & \\
\hline N1 & & & $(0,816)$ & & & & \multirow{2}{*}{0,667} \\
\hline $\mathrm{N} 2$ & & & $(0,789)$ & & & & \\
\hline NP1 & & & & $(0,784)$ & & & \multirow{2}{*}{0,615} \\
\hline NP2 & & & & $(0,784)$ & & & \\
\hline KPE1 & & & & & $(0,700)$ & & \multirow{2}{*}{0,649} \\
\hline KPE2 & & & & & $(0,785)$ & & \\
\hline $\mathrm{S} 1$ & & & & & & $(0,934)$ & \multirow{2}{*}{0,868} \\
\hline S2 & & & & & & $(0,922)$ & \\
\hline
\end{tabular}

Sumber: Data diolah (2017) 
Tabel 2 menunjukan bahwa semua indikator valid. Hal ini karena dapat dilihat nilai loading yang lebih besar dari 0,7 dan nilai AVE yang lebih besar dari 0,5.

\section{b. Uji Reliabilitas}

Uji realibilitas bertujuan untuk mengukur konsistensi internal alat ukur. Parameter yang digunakan untuk uji reliabilitas yaitu composite reliability dengan nilai rule of thumb lebih besar dari 0,7 akan tetapi 0,6 juga masih dapat diterima (Hair et al., 2008). Hasil reliabilitas disajikan pada tabel 3 .

Tabel 3

Hasil Uji Reliabilitas

\begin{tabular}{|c|c|c|c|c|c|c|}
\hline & KP & PK & N & NP & KPE & S \\
\hline Nilai Composite Reliabilty & 0,822 & 0,8221 & 0,800 & 0,762 & 0,787 & 0,929 \\
\hline
\end{tabular}

Sumber: Data diolah (2017)

Tabel 3 menjelaskan hasil reliabilitas dengan menggunakan metode Composite reliability. Rule of thumb nilai composite reliability lebih besar 0,7 . Oleh karena itu, penelitian ini memenuhi uji reliabilitas.

\section{Model Struktural (inner Model)}

Penelitian ini telah memenuhi pengujian model pengukuran (outer model), tahap selanjutnya yang dilakukan ini yaitu pengujian model struktural (inner model). Pengujian model struktural (inner model) dilakukan dengan menggunakan $R$-square, dan nilai koefisien path atau $t$-value tiap path. Hasil $R$-square disajikan pada tabel 4.

Tabel 4

Nilai $R-S q u a r e$

\begin{tabular}{|c|c|}
\hline Konstruk & $R$-square \\
\hline PK & - \\
\hline N & - \\
\hline KPE & - \\
\hline KP & 0,391 \\
\hline S & 0,206 \\
\hline NP & 0,299 \\
\hline
\end{tabular}

Sumber: Data diolah (2017)

$R$-square $\left(\mathrm{R}^{2}\right)$ digunakan untuk mengevaluasi konstruk dependen dalam model struktural. Nilai $R$-square digunakan untuk mengukur tingkat variasi perubahan variabel independen terhadap variabel dependen (Hartono dan Abdillah 2014).

Tabel 4 menunjukan bahwa kegunaan persepsian memiliki nilai $R$-square 0,391 . Hal ini berarti bahwa variasi perubahan variabel kemudahaan persepsian yang dapat dijelaskan oleh variabel kemudahaan penggunaan persepsian adalah $39,1 \%$, sedangkan sisanya dijelaskan oleh variabel lain diluar model penelitian.

Sikap pengguna terhadap media sosial memiliki $R$-square 0,206 . Hal ini berarti bahwa variasi perubahan variabel sikap pengguna terhadap media sosial dijelaskan oleh variabel 
kegunaan persepsian dan kemudahaan penggunaan sebesar 20,6\%, sedangkan sisanya dijelaskan oleh variabel lain diluar model.

Niat untuk melakukan pembelian melalui media sosial memiliki nilai $R$-square 0,299 . Hal ini berarti bahwa variasi perubahan variabel niat untuk melakukan pembelian melalui media sosial dijelaskan oleh variabel sikap pengguna terhadap media sosial, norma subjektif, dan kontrol perilaku persepsian sebesar $29,9 \%$, sedangkan sisanya dijelaskan oleh variabel lain diluar model.

Tingkat signifikasi dalam pengujian hipotesis dapat diketahui dengan menggunakan nilai koefisien path atau inner model (Hartono dan Abdillah, 2014). Hasil pengujian inner model disajikan pada tabel 5 .

Tabel 5

Ringkasan Hasil Inner Model

\begin{tabular}{|c|c|c|c|}
\hline & Koefisien $(\boldsymbol{\beta})$ & Signifikasi & Keterangan \\
\hline $\mathrm{H}_{1}: \mathrm{KP} \rightarrow \mathrm{S}$ & 0,17 & 0,04 & Terdukung \\
\hline $\mathrm{H}_{2}: \mathrm{PK} \rightarrow \mathrm{S}$ & 0,33 & $<0,01$ & Terdukung \\
\hline $\mathrm{H}_{3}: \mathrm{PK} \rightarrow \mathrm{KP}$ & 0,63 & $<0,01$ & Terdukung \\
\hline $\mathrm{H}_{4}: \mathrm{KP} \rightarrow \mathrm{NP}$ & $-0,07$ & 0,34 & Tidak Terdukung \\
\hline $\mathrm{H}_{5}: \mathrm{S} \rightarrow \mathrm{NP}$ & 0,48 & $<0,01$ & Terdukung \\
\hline $\mathrm{H}_{6}: \mathrm{N} \rightarrow \mathrm{NP}$ & 0,07 & 0,21 & Tidak Terdukung \\
\hline $\mathrm{H}_{7}: \mathrm{KPE} \rightarrow \mathrm{NP}$ & 0,05 & 0,30 & Tidak Terdukung \\
\hline
\end{tabular}

Sumber: Data diolah, 2017

Keterangan:

KP : Kegunaan Persepsian

PK : Kemudahaan Penggunaan Persepsian

N : Norma Subjektif

NP : Niat Untuk Melakukan Pembelian Melalui Media Sosial

KPE : Kontrol Perilaku Persepsian

S : Sikap Pengguna Terhadap Media Sosial

Tabel 5 menunjukan bahwa kegunaan persepsian mempunyai pengaruh positif terhadap sikap pengguna pada media sosial. Hal ini ditunjukan dengan nilai koefisien $(+0,17)$ serta nilai signifikasi $(0,04)<0,05$. Oleh karena itu, individu yang mempunyai persepsi bahwa media sosial memiliki manfaat bagi dirinya, maka individu tersebut akan merespon baik keberadaan media sosial tersebut, dan sebaliknya. Sehingga, hipotesis pertama penelitian ini terdukung. Hasil ini didukung oleh penelitian Putri dan Suprapti (2016) serta Sari dan Hermanto (2016). Putri dan Suprapti (2016) menyatakan bahwa persepsi kegunaan menentukan niat menggunakan m-commerce secara tidak langsung melalui sikap penggunaan. Sedangkan, Sari dan Hermanto (2016) menemukan hasil bahwa persepsi kegunaan berpengaruh positif terhadap sikap penggunaan.

Kemudahaan penggunaan persepsian berpengaruh positif terhadap sikap pengguna terhadap media sosial. Hal ditunjukan dengan nilai koefisien $(+0,33)$ dan nilai signifikasi $(<$ $0,01)$ yang kurang dari 0,05 . Sehingga, individu yang mempunyai persepsi bahwa media sosial tersebut mudah digunakan oleh dirinya, maka individu tersebut akan merespon 
keberadaan media sosial tersebut. Oleh karena itu, hipotesis kedua penelitian ini terdukung. Hasil ini didukung oleh penelitian Putri dan Suprapti (2016) dan Salsabila et al (2016). Putri dan Suprapti (2016) yaitu persepsi kemudahaan penggunaan menentukan niat menggunakan m-commerce secara tidak langsung melalui sikap penggunaan. Begitu juga, Salsabila et al (2016), kemanfaatan mempunyai pengaruh positif dan signifikan terhadap sikap penggunaan.

Hipotesis ketiga penelitian ini yang menyatakan bahwa kemudahaan penggunaan persepsian berpengaruh positif terhadap kegunaan persepsi terdukung. Hal ini ditunjukan dengan nilai koefisien $(+0,63)$ dan nilai signifikasi $<0,01$. Nilai signifikasi $(<0,01)$ lebih kecil dari 0,05. Oleh karena itu, ketika individu mempunyai persepsi bahwa media sosial mudah digunakan maka individu tersebut juga mengganggap media sosial berguna bagi dirinya. Hasil ini didukung oleh penelitian Tirtana dan Sari (2014); Paramitha dan Mujahidin (2014); Sari dan Hermanto (2016), yang menyatakan bahwa persepsi kemudahaan penggunaan dalam e-bill akan mempengaruhi persepsi kegunaan yang digambarkan sebagai kemudahaan yang dirasakan oleh pengguna dalam menggunakan e-bill akan memudah akses pengguna untuk menemukan informasi yang dibutuhkan.

Kegunaan persepsi tidak berpengaruh terhadap niat untuk melakukan pembelian melalui media sosial. Hal ini ditunjukan dengan nilai signifikasi $(0,34)$ yang lebih besar dari 0,05 . Sehingga, hipotesis keempat penelitian ini tidak terdukung. Ketidak terdukungan hipotesis keempat diperkuat oleh hasil penelitian Kazi (2013); Alam et al (2009), yang menyatakan bahwa faktor kemudahaan penggunaan tidak berpengaruh terhadap niat untuk mengadopsi internet banking. Ketidak terdukungan hipotesis ketiga yang menyatakan bahwa kegunaan persepsi berpengaruh terhadap niat untuk melakukan pembelian melalui media sosial, mungkin disebabkan oleh beberapa hal. Pertama, responden mungkin berasumsi bahwa untuk menggunakan media sosial tidak dibutuhkan usaha yang keras. Kedua, responden sudah familiar dengan media sosial, sehingga penggunaan media sosial untuk pembelian dirasakan mudah dalam penggunaannya.

Hipotesis kelima yang menyatakan bahwa sikap pengguna pada media sosial berpengaruh positif terhadap niat untuk melakukan pembelian melalui media sosial terdukung. Hal ini ditunjukan dengan nilai koefisien $(+0,48)$ serta nilai signifikasi $(<0,01)$ yang kurang dari 0,05 . Oleh karena itu, ketika individu merespon media sosial dengan baik, maka individu terdorong untuk melakukan pembelian melalui media sosial tersebut. Hal ini didukung oleh penelitian Putri dan Suprapti (2016). Putri dan Suprapti (2016), mengungkapkan bahwa kegunaan persepsian dan persepsi kemudahaan penggunaan menentukan niat menggunakan mobile commerce secara langsung melalui sikap penggunaan.

Norma subjektif tidak berpengaruh terhadap niat untuk melakukan pembelian melalui media sosial. Hal ini ditunjukan dengan nilai signifikasi $(0,21)$ yang lebih besar dari 0,05 . Sehingga, hipotesis keenam penelitian ini tidak terdukung. Begitu pula, dengan hipotesis ketujuh, yang menyatakan bahwa kontrol perilaku persepsian berpengaruh terhadap niat untuk melakukan pembelian melalui media sosial. Ketidakterdukungan hipotesis keenam dan ketujuh mungkin disebabkan oleh beberapa faktor. Pertama, responden mungkin mempertimbangkan keamanan saat akan melakukan pembelian melalui media sosial. Kedua, responden mungkin berasumsi bahwa untuk menggunakan media sosial tidak dibutuhkan usaha yang keras. Ketiga, responden sudah familiar dengan media sosial, sehingga penggunaan media sosial untuk pembelian dirasakan mudah dalam penggunaannya. Keempat, responden mengganggap media sosial tersebut dirasa berguna bagi dirinya dan mudah digunakan, sehingga responden tidak perlu dorongan dari orang lain untuk melakukan pembelian melalui media sosial. 


\section{SIMPULAN}

Sikap pengguna terhadap media sosial dipengaruhi oleh kegunaan persepsian dan kemudahaan penggunaan persepsian. Sehingga, ketika individu merasa bahwa media sosial yang digunakan bermanfaat dan mudah digunakan, maka sikap individu terhadap media sosial yang digunakan juga baik, dan sebaliknya ketika individu merasa bahwa media sosial yang digunakan tidak bermanfaat dan sulit digunakan, maka sikap individu terhadap media sosial tersebut juga negatif. Akhirnya, ketika individu mempunyai sikap yang positif pada media sosial yang digunakan, individu akan terdorong untuk melakukan pembelian melalui media sosial. Sebaliknya, ketika individu mempunyai sikap yang negatif pada media sosial yang digunakan, individu akan enggan untuk melakukan pembelian melalui media sosial tersebut.

Persepsi kegunaan pengguna dipengaruhi oleh kemudahan penggunaan persepsian. Oleh karena itu, ketika pengguna merasa bahwa media sosial tersebut mudah digunakan, maka pengguna merasa bahwa media sosial tersebut bermanfaat bagi dirinya. Sebaliknya, jika pengguna merasa bahwa media sosial tersebut sulit digunakan, maka pengguna mungkin merasa media sosial tersebut tidak memberi manfaat baginya, karena ketika pengguna kesulitan menggunakan media sosial tersebut, pengguna akan memerlukan banyak waktu dalam menggunakan media sosial tersebut.

Kegunaan persepsian tidak berpengaruh terhadap niat untuk melakukan pembelian melalui media sosial. Hal ini mungkin disebabkan oleh beberapa faktor. Pertama, responden mungkin berasumsi bahwa untuk menggunakan media sosial tidak dibutuhkan usaha yang keras. Kedua, responden sudah familiar dengan internet, sehingga penggunaan media sosial untuk pembelian dirasakan mudah dalam penggunaannya.

Norma subjektif dan kontrol perilaku persepsian tidak berpengaruh terhadap niat untuk melakukan pembelian melalui media sosial. Hal ini mungkin disebabkan oleh beberapa faktor. Pertama, responden mungkin mempertimbangkan keamanan saat akan melakukan pembelian melalui media sosial. Kedua, responden mungkin berasumsi bahwa untuk menggunakan media sosial tidak dibutuhkan usaha yang keras. Ketiga, responden mengganggap media sosial tersebut dirasa berguna bagi dirinya dan mudah digunakan, sehingga responden tidak perlu dorongan dari orang lain untuk melakukan pembelian melalui media sosial.

Penelitian ini mepunyai beberapa keterbatasan. Pertama, Penelitian ini menggunakan metode survey sehingga, penelitian ini memiliki validitas internal yang rendah. Kedua, penelitian ini tidak fokus pada media sosial yang digunakan responden untuk melakukan pembelian, missal instagram, line, whatshapp, dan lain-lain. Oleh karena itu, penelitian selanjutnya diharapkan menggunakan metode eskperimen, dan fokus pada satu media sosial yang digunakan untuk melakukan pembelian, misal instragram, website, maupun facebook.

\section{DAFTAR PUSTAKA}

Ajzen, Icek. (1988). Attitudes, Personality, and Bahavior. Chicago: Dorsey Press

Ajzen, Icek. (1991). The Theory of Planned Behavior. Organizational Behavior and Human Decision Process, Vol 50, hal 179-211

Ajzen, I, dan M. Fishbein. (1980). Understanding Attitudes and Predicting Social Behavior. Englewood Cliffs: Prentice Hall

Alam, S.S., Musa R., Hasan F. (2009). Corporate Customers' Adoption Internet of Internet Banking: Casa of Klang Vally Business Firm in Malaysia. International Journal of Business and Management, Vol 4, N0 4.

Ashur, Muhammad. (2016). Pengaruh Dukungan Sosial, Persepsi Risiko, dan Interaksi Sosial Terhadap Kepercayaan dan Niat Pembelian Konsumen Pada Media S-Commerce (Studi Pada Konsumen S-Commerce di Indonesia). Jurnal Bisnis dan Manajemen, Vol 3, No 1, hal 109-119

Bagozzi RP., Yi Y., Phillips, LW. (1991). Assesung Construct Validity in Organizational Research. Admin Sci Quarts, Vol 36, No 3, hal 421-430

Binalay, Andrew Gustnest., S.L, Mandey, dan C.M.O, Mintardjo. (2016). Pengaruh Sikap, Norma Subjektif, dan Motivasi Terhadap Minat Beli Secara Online Pada Mahasiswa Fakultas Ekonomi dan Bisnis di Manado. Jurnal EMBA, Vol 4, No 1, hal 395-406

Cooper, Donal R, dan P. S. Schindler. (2006). Business Research Model. Newyork: McGrawHill/Irwin 
Davis, F.D., Bagozzi, R.P., dan Warshaw, P.L. (1989). User Acceptance of Computer Technology: A Comparison of Two Theoritical Model. Management Science, Vol 32, hal 982-100

Dennison, G., Bourdage-Braun, S., dan Chetuparambil. (2009). Social commerce Defined. IBM Corporation

Engel, James F., R.D, Blackwell., dan P.W, Miniard. (1994). Consumer Behavior. New York: Holt, Rinehart, and Wiston.

Hair, J.F., W.C. Black., B.J. Babin., R.E. Anderson, dan R.L. Tatham. (2008). Multivariate data Analysis. Edisi 6. Pearson Prentice Hall

Hajli, M. (2014). The Role of Social Support on Relationship Quality and Social commerce. Technology Forecasting \& Social change, Vol 87, hal 17-27

Hartono, Jogiyanto. (2007). Sistem Informasi Keperilakuan, Edisi 1. Yogyakarta, Indonesia: ANDI OFFSET

Hartono, Jogiyanto. (2008). Metodologi Penelitian Sistem Informasi. Edisi 1. Yogyakarta, Indonesia: ANDI OFFSET

Hartono, Jogiyanto, dan W. Abdillah. (2014). Konsep dan Aplikasi (Partial Least Square) untuk Penelitian Empiris. Edisi 1. Yogyakarta, Indonesia: BPFE UGM

Heriyanti, Nining., Firdaus, M. R., dan Rusmiyati. (2013). Analisis Belanja Online Melalui Smartphone Dengan Menggunakan Extended Technology Aceptance Model. Jurnal Wawasan Manajemen, Vol 1, No 3, hal 343-406

Https://kominfo.go.id/index.php/content/detail/3415/Kominfo+\%3A+Pengguna+Internet + di + Indonesia+63+Juta+Orang/0/berita satker dilihat tanggal 2 Nov 2016, Pukul 5:30)

Huang, Z., dan Benyoucef, M. (2013). From E-Commerce to Social Commerce: A Close Look at Design Features. Electronic Commerce Research and Aplication, Vol 12, No 4, hal 246-259

Indrayana, Bayu., Seminar, Kudang Boro, dan Sartono, Bagus. (2016). Faktor Penentu Minat Penggunaan Instagram Untuk Pemberian Online Menggunakan Technology Acceptance Model (TAM) dan Theory of Planned Behavior (TPB). Jurnal Aplikasi Bisnis dan Manajemen, Vol 2, No 2, hal 138-147

Kazi, A.K. (2013). An Emirical Study of Factors Influencing Adoption of Internet Banking Among Students of Higher Education: Evidence from Pakistan. International Journal of Finance and Banking Studies, Vol 2, No 2

Kim, S., dan Park, H. (2013). Effect of Various Characteristics of Social Commerce (SCommerce) Consumers' Trust and Trust Performance. International Journal of Information Management, Vol 33, hal 318-332

Liang, T., Ho, Y., Li, Y, dan Turban, E. (2012). What Drives Social Commerce: The Role of Social Support and Relationship Quality. International Journal of Electronic Commerce, Vol 16, No 2, hal 69-90

Pradana, Aditya Wahyu., Susilo, Heru, dan Riyadi. (2016). Pengaruh Persepsi Kemudahaan, kemanfaatan, dan Sikap Pengguna Terhadap Minat Menggunakan IFS Software (Studi Pada Departemen Pengadaan Barang dan Jasa PT Petrokimia (Gresik). Jurnal Administrasi Bisnis, Vol 36, No 1, hal 1-9

Putri, Ni Made Kania Indriani dan Suprapti, Ni Wayan Sri. (2016). Aplikasi Model TAM Dalam Menjelaskan Niat Menggunakan Mobile Commerce di Kota Denpasar. EJurnal Manajemen UNUD, Vol 5, No 4, hal 2341-2368

Ramadhani, N. 2007. Model Perilaku Penggunaan NR 2007 Pengembangan Dari Technology Acceptance Model. Buletin TSM

Salsabila, Denada Violy., Susilo, Heru, dan Dewantara, Rizky. (2016). Pengaruh Kemudahaan Penggunaan dan Kemanfaatan Terhadap Sikap Pengguna Sistem (Studi Pada Mahasiswa Fakultas Ilmu Administrasi Jurusan Administrasi Publik Universitas Brawijaya). Jurnal Administrasi Bisnis, Vol 36, No 1, hal 48-57

Santoso, Budi. (2010). Pengaruh Perceived Usefulness, Perceiver Ease of Use, dan Perceived Enjoyment Terhadap Penerimaan Teknologi Inforormasi: Studi Empiris di Kabupaten Sragen. Tesis Fakultas Ekonomi Universitas Sebelas Maret

Sari, Ema Novita, dan Hermanto, Suwardi Bambang. (2016). Analisis Faktor dalam Menggunakan Layanan E-Bill dengan Pendekatan Technology Acceptance Model (TAM). Jurnal Ilmu dan Riset Akuntansi, Vol 5, No 4, hal 1-23

Shin, D.H. (2013). User Experience in Social commerce: in Friends We Trust. Behavioral Information Technology, Vol 32, hal 52-67

Smith, Sheila M., Zhao, Jensen, dan Alexander, Melody. (2013). Social Commerce from a Theory of Planned behavior Paradigm: An Analysis of Purchase Intention. International Journal of E-Adoption, Vol 5, No 3, hal 76-88

Stephen, A, dan Toubia, O. (2010). Deriving Value from Social Commerce Network. Journal 
of Marketing Research, Vol 47, hal 215-228

Thakur, Rakhi, dan Srivastara, Mala. (2013). Customer Usage Intention of Mobile Commerce in India: An Empirical Study. Journal of India Businewss Research, Vol 5, No 1, hal $52-72$

Tirtana, I, dam S.P. Sari. (2014). Analisis Pengaruh Persepsi Kebermanfaatan, Persepsi Kemudahaan dan Kepercayaan terhadap Penggunaan Mobile Banking. Seminar Nasional dan Call Paper, Vol 25 Juni 2014: 671-687

Zhou, L., Zhang, P., dan Zimmermann, H.D. (2013). Social commerce: an Integrated View. Electronic Commerce Research and Application, Vol 12, No 2, hal 61-68 